\title{
Reduced inspiratory flow attenuates IL-8 release and MAPK activation of lung overstretch
}

\author{
M. Kotani*, , T. Kotani*», Z. Li" ${ }^{\#}$, R. Silbajoris ${ }^{\Uparrow}$, C.A. Piantadosi*, Y-C.T. Huang*,
}

Reduced inspiratory flow attenuates IL-8 release and MAPK activation of lung overstretch. M. Kotani, T. Kotani, Z. Li, R. Silbajoris, C.A. Piantadosi, Y-C.T. Huang. (C) ERS Journals Ltd 2004.

ABSTRACT: Lung overstretch involves mechanical factors, including large tidal volumes $(V T)$, which induce inflammatory responses. The current authors hypothesised that inspiratory flow contributes to ventilator-induced inflammation.

Buffer-perfused rabbit lungs were ventilated for $2 \mathrm{~h}$ with $21 \% \mathrm{O}_{2}+5 \% \mathrm{CO}_{2}$, positive end-expiratory pressure of $2-3 \mathrm{cmH}_{2} \mathrm{O}$ and randomly assigned to either: 1) normal $V_{T}$ $\left(6 \mathrm{~mL} \cdot \mathrm{kg}^{-1}\right)$ at respiratory rate $(\mathrm{RR}) 30$, inspiration:expiration time ratio (I:E) 1:1, low inspiratory flow $\left.6 \mathrm{~mL} \cdot \mathrm{kg}^{-1} \cdot \mathrm{s}^{-1} ; 2\right)$ large $V_{T}\left(12 \mathrm{~mL} \cdot \mathrm{kg}^{-1}\right)$ at RR 30, I:E 1:1, high inspiratory flow $12 \mathrm{~mL} \cdot \mathrm{kg}^{-1} \cdot \mathrm{s}^{-1}$ (HRHF); 3) large $V$ T at RR 15, I:E 1:1, low inspiratory flow $6 \mathrm{~mL} \cdot \mathrm{kg}^{-1} \cdot \mathrm{s}^{-1}$ (LRLF); or 4) large $V_{T}$ at RR 15, I:E 1:2.3, high inspiratory flow $10 \mathrm{~mL} \cdot \mathrm{kg}^{-1} \cdot \mathrm{s}^{-1}$ (LRHF). Physiological parameters, tumour necrosis factor (TNF)- $\alpha$, interleukin (IL)-8 and activation of mitogen-activated protein kinases (extracellular signal-regulated kinase (ERK)1/2, p38 and stress-activated protein kinase (SAPK)l c-Jun N-terminal kinase (JNK)) were measured.

HRHF increased weight gain, perfusate IL-8 and phosphorylation of ERK1/2, p38 and SAPK/JNK. These responses were absent during LRLF but present during LRHF. Changes in TNF- $\alpha$ were small. Tissue IL-8 and phospho-ERK1/2 staining was localised primarily to smooth muscle, adventitia and bronchial epithelium within larger bronchioles and arterioles.

These results indicate that mild overstretch of perfused lungs during high inspiratory flow enhances inflammatory signalling by cells in lung regions most affected by strong turbulent airflow.

Eur Respir J 2004; 24: 238-246.
*Depts of Anesthesiology and Medicine, Duke University Medical Center, Durham, ${ }^{\#}$ Center for Environmental Medicine, Asthma and Lung Biology, University of North Carolina, Chapel Hill, and "National Health and Environmental Effects Research Laboratory Office of Research and Development, Environmental Protection Agency, Research Triangle Park, North Carolina, USA.

Correspondence: Y-C.T. Huang, CB 7315, 104 Mason Farm Road, Chapel Hill, NC 27599, USA

Fax: 19199666271

E-mail: huang.tony@epa.gov

Keywords: Acute lung injury, inspiratory flow, interleukin-8, mechanical ventilation, mitogenactivated protein kinase

Received: November 192003

Accepted after revision: March 102004

${ }^{\S}$ These authors contributed equally to the study.

The research described in this article has been reviewed by the Health Effects and Environmental Research Laboratory, United States Environmental Protection Agency and has been approved for publication. Approval does not signify that the contents necessarily reflect the views and policies of the Agency, nor does mention of the trade names or commercial products constitute endorsement or recommendation for use.
During mechanical ventilation, the lung is subjected to mechanical forces that produce overstretch, compression, and shear stress on bronchial and alveolar structures. Overstretch by high tidal volumes $(V \mathrm{~T})$ may produce overt lung oedema due to physical injury to alveolar-capillary membrane $[1,2]$ while milder overstretch causes less direct injury. However, lung injury may still occur due to activation of intracellular signalling pathways and subsequent release of inflammatory cytokines and chemokines [3-6]. In patients with acute lung injury, additional injury caused by such mechanical stress (ventilator-induced lung injury (VILI)) contributes to morbidity and mortality [7].

The mechanisms of VILI have been attributed to stress and strain by lung overstretching at high $V$ T/pressure ventilation. Ventilation of unperfused isolated rat lungs with $40 \mathrm{~mL} \cdot \mathrm{kg}^{-1}$ of $V \mathrm{~T}$ increases chemokines (macrophage inflammatory protein (MIP)-2) and inflammatory cytokines (tumour necrosis factor (TNF)- $\alpha$, interleukin (IL)-1 $\beta$, IL-6) in the airspaces [8]. Ventilation of rats at $20 \mathrm{~mL} \cdot \mathrm{kg}^{-1}$ for $2 \mathrm{~h}$ increases MIP-2 in the bronchoalveolar lavage (BAL) fluid [9]. Ventilation of mice at $24 \mathrm{~mL} \cdot \mathrm{kg}^{-1}$ for $6 \mathrm{~h}$ increases MIP-2 expression in lung homogenate, and in association with increased microvascular permeability and lung injury [3]. Ventilation of isolated mouse lungs with $15 \mathrm{~mL} \cdot \mathrm{kg}^{-1}$ increases MIP-2, TNF- $\alpha$ and IL-6 release into the perfusate [10-13]. In vivo ventilation of rabbits with $12-15 \mathrm{~mL} \cdot \mathrm{kg}^{-1}$ for $4 \mathrm{~h}$ increases TNF- $\alpha$ concentration in BAL [14]. Ventilation of rats at high inspiratory pressure and positive end-expiratory pressure (PEEP; $45 / 10 \mathrm{cmH}_{2} \mathrm{O}$ ) activates mitogen-activated protein kinase (MAPK) and nuclear factor- $\kappa \mathrm{B}$ pathways [15]. These in vivo and ex vivo effects are supported by many in vitro studies, in which cultured lung epithelial cells [6, 16-19], endothelial cells [20-21] and macrophages [5] have been subjected to overstretch.

Inspiratory flow rate is also an important determinant of stress in the lung. High inspiratory flow enhances tensile stress across alveolar surfaces resulting in greater transmission of kinetic energy to underlying structures despite the same volume change. High inspiratory flow also increases shear stress parallel to the surface of the airways and alveolar walls, distorting lung parenchyma and deforming bronchial epithelial cells with little change in volume [22]. High inspiratory 
flow is frequently needed to deliver adequate $V T$, but an independent contribution of inspiratory flow to lung stretchinduced biochemical responses has not been determined.

The purpose of this study was to determine whether high inspiratory flow activates intracellular signalling pathways of inflammation. This hypothesis was tested in isolated bufferedperfused lung ventilated with a moderate $V \mathrm{~T}\left(12 \mathrm{~mL} \cdot \mathrm{kg}^{-1}\right)$. Inspiratory flows were varied by adjusting respiratory rate (RR) and inspiratory:expiratory time ratio (I:E). The current authors then measured release of IL- 8, TNF- $\alpha$ and activation of MAPK, all of which have been linked to the development of VILI [3, 8-15]. The buffer-perfused lung system was used specifically to remove inflammatory effects produced by activated nonresident inflammatory cells migrating into the lung. This model has been shown to release chemokine/ cytokine and protein kinase activation in response to various stimuli in the present authors' laboratory [23-26].

\section{Material and methods}

\section{Isolated perfused lung preparation}

The experimental protocol was approved by the Institutional Animal Care and Use Committee of Duke University. Isolation and perfusion of the lung was performed according to published techniques from this laboratory [24-26]. Briefly, New Zealand White rabbits (3.0-3.6 kg; Robinson's Farm, Clemens, NC, USA) were heparinised and anesthetised. The chest wall was opened, and the left atrium and the main pulmonary artery were cannulated. The aorta was also ligated to prevent loss of perfusate through the left ventricle. The circuit was washed free of blood with Krebs-Henseleit-3\% albumin buffer. The perfusion circuit consisted of a reservoir, a roller pump (Sarns, Inc., Ann Arbor, MI, USA) a bubble trap and a heat exchanger, connected with Tygon tubing. The reservoir for collecting perfusate from the left atrium was suspended freely from a force transducer (Model FT100; Grass Instrument Company, Quincy, MA, USA), and was levelled against the left atrium. Weight gain (WG) of the lung was measured by recording the loss of fluid from the reservoir. The fluid volume of the system was approximately $250 \mathrm{~mL}$. The lungs were ventilated with $21 \% \mathrm{O}_{2}+5 \% \mathrm{CO}_{2}$ and a PEEP of $2-3 \mathrm{cmH}_{2} \mathrm{O}$ with an animal respirator (Harvard Apparatus, Inc., Holliston, MA, USA). The gas mixture contained $5 \% \mathrm{CO}_{2}$ to maintain a perfusate partial pressure of $\mathrm{CO}_{2}$ of $35-40 \mathrm{mmHg}$ [27] to minimise the effects of hypocapnea on cytokine release [28]. The re-circulating flow rate was $100 \mathrm{~mL} \cdot \mathrm{min}^{-1}$. The air flow was measured at the proximal end of the tracheostomy tube by a bidirectional Fleisch pneumotachometer (No. 001206; Fleisch, Lausanne, Switzerland) connected to a differential pressure transducer (Statham, PM15, Hato Rey, PR, USA) to measure airflow rates up to $150 \mathrm{~mL} \cdot \mathrm{s}^{-1}$. WG, pulmonary artery pressure $(P \mathrm{pa})$, airway pressure $(P$ aw $)$ and air flow were recorded via a 4-channel analog-to-digital converter connected to a PC computer equipped with a data acquisition software (DATAQ
Instruments, Inc. Akron, OH, USA). The initial $V \mathrm{~T}$ was $6 \mathrm{~mL} \cdot \mathrm{kg}^{-1}$, which produced peak $P$ aw of $7-10 \mathrm{mmHg}$. Lungs were excluded if there were gross leaks or if the $P$ pa was $>20 \mathrm{mmHg}$ during the 10 -min stabilisation period. The perfusion buffer contains $\mathrm{NaCl}(82.8 \mathrm{mM}), \mathrm{KCl}(4.7 \mathrm{mM})$, $\mathrm{KH}_{2} \mathrm{PO}_{4}(2.4 \mathrm{mM}), \mathrm{NaHCO}_{3}(25 \mathrm{mM}), \mathrm{MgSO}_{4}(1.2 \mathrm{mM})$, $\mathrm{CaCl}_{2}(2.7 \mathrm{mM})$, dextrose $(11.1 \mathrm{mM})$, and bovine serum albumin (BSA), fraction $\mathrm{V}(3 \%, \mathrm{w} / \mathrm{v})$.

\section{Ventilation protocols}

Lungs were randomly assigned to ventilation at either normal $V \mathrm{~T}$ of $6 \mathrm{~mL} \cdot \mathrm{kg}^{-1}$ (the control group) or large $V \mathrm{~T}$ of $12 \mathrm{~mL} \cdot \mathrm{kg}^{-1}$ (table 1). In the large $V \mathrm{~T}$ group, three different protocols were used: 1) high RR with high inspiratory flow (HRHF); 2) low RR with high inspiratory flow (LRHF) and 3) low RR with low inspiratory flow (LRLF) (Table 1). These three groups represented the same high volume stretch but different inspiratory flow and respiratory rates. In HRHF, $V \mathrm{~T}$ was increased, which also increased inspiratory flow rate since RR and I:E were unchanged. In LRLF, RR was decreased by $50 \%$ to create a lower inspiratory flow rate matching that of the control group. In LRHF, I:E ratio was decreased to match the high inspiratory flow of the HRHF group while RR remained low like LRLF. Typical tracings of air flow and airway pressure for the four groups are shown in figure 1. Air trapping was absent in all groups as indicated by zero flow at end-expiration (fig. 1a-d). Lungs were ventilated and perfused for $120 \mathrm{~min}$. Serial 2-mL perfusate samples were taken from the effluent port and BAL was performed at the end of the experiment [29]. All fluid samples were stored at $-80^{\circ} \mathrm{C}$ until analysis.

\section{Measurement of epithelial permeability}

Epithelial permeability was estimated from BAL bovine albumin concentration measured using a bovine albumin ELISA quantitation kit (Bethyl Laboratories, Inc., Montgomery, TX, USA) according to manufacturer's recommendations. The lower detection limit for the assay was $6 \mathrm{ng} \cdot \mathrm{mL}^{-1}$.

\section{Measurements of tumour necrosis factor- $\alpha$ and interleukin-8}

Concentrations of TNF- $\alpha$ and IL- 8 in perfusate and BAL fluid were measured using ELISA kits according to manufacturer's recommendations (R\&D Systems, Inc., Minneapolis, MN, USA).

\section{Immunohistochemistry}

Lungs were inflation fixed using 4\% paraformaldehyde at $20 \mathrm{cmH}_{2} \mathrm{O}$ pressure and embedded in paraffin. The lung

Table 1. - Ventilatory protocols

\begin{tabular}{lcccc}
\hline \multicolumn{1}{c}{ Groups } & Respiratory rate $\mathrm{bpm}$ & Average flow $\mathrm{mL} \cdot \mathrm{kg}^{-1} \cdot \mathrm{s}^{-1}$ & I:E ratio & Inspiratory time s \\
\hline $6 \mathrm{~mL} \cdot \mathrm{kg}^{-1}$ & 30 & 6 & $1: 1$ & 1.0 \\
$12 \mathrm{~mL} \cdot \mathrm{kg}^{-1}+\mathrm{HRHF}$ & 30 & 12 & $1: 2.3$ & 1.0 \\
$12 \mathrm{~mL} \cdot \mathrm{kg}^{-1}+\mathrm{LRHF}$ & 15 & 10 & $1: 1$ & 1.2 \\
$12 \mathrm{~mL} \cdot \mathrm{kg}^{-1}+\mathrm{LRLF}$ & 15 & 6 & 2.0 \\
\hline
\end{tabular}

HRHF: high respiratory rate high inspiratory flow; LRHF: low respiratory rate high inspiratory flow; LRLF: low respiratory rate low inspiratory flow; I:E ratio: inspiration:expiration time ratio. 
240

M. KOTANI ET AL.
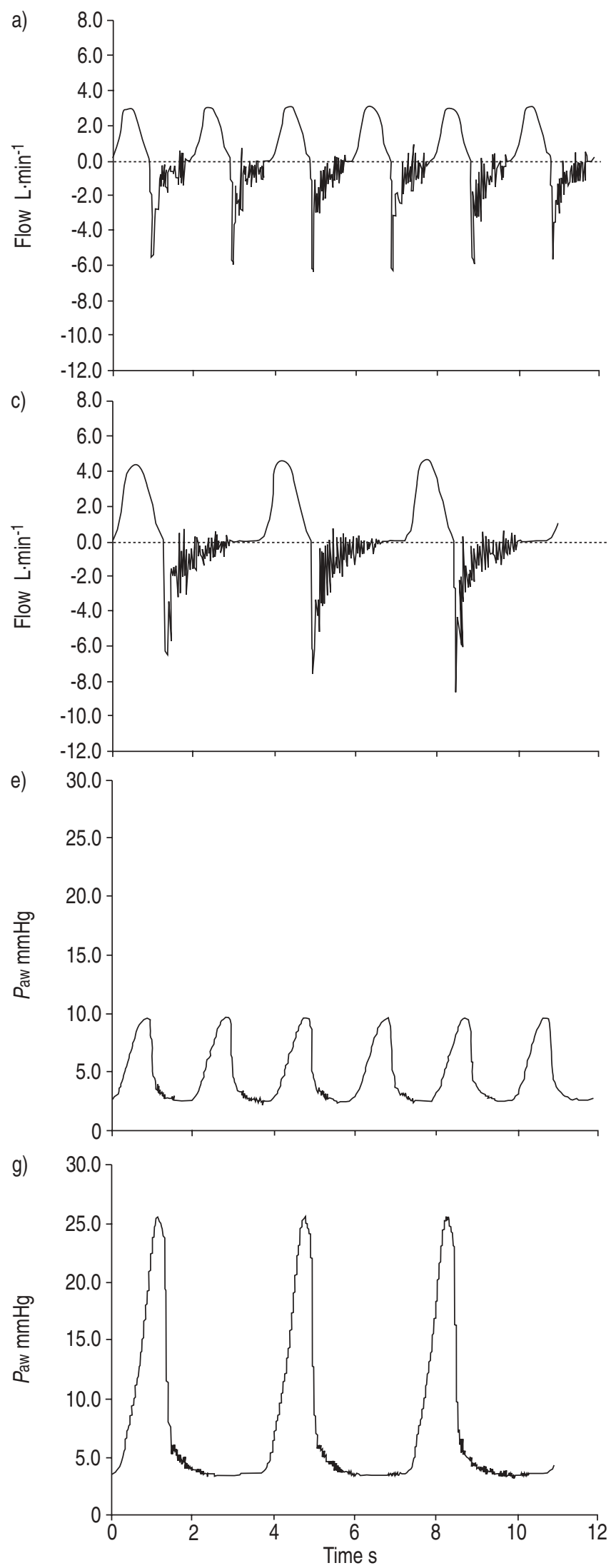

b)

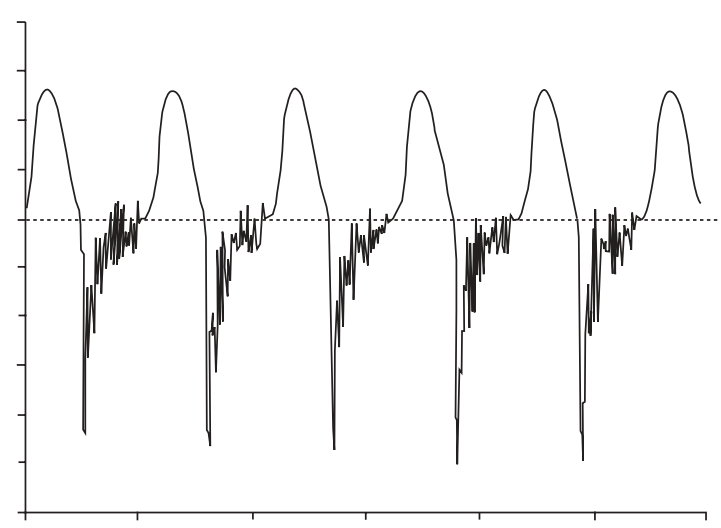

d)



f)

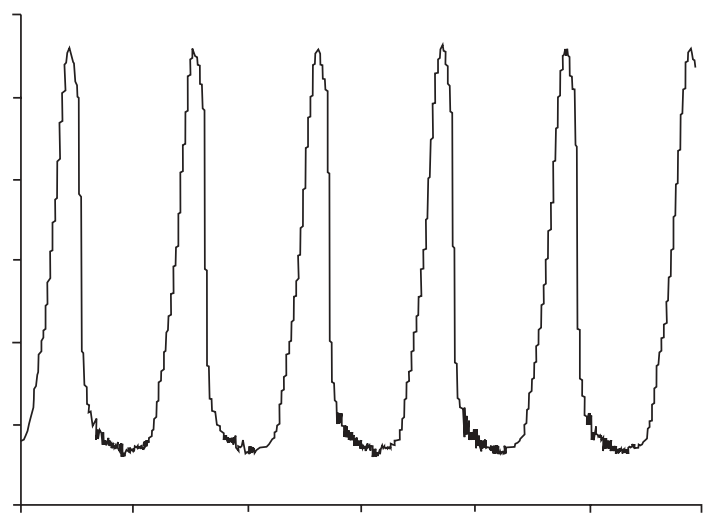

h)

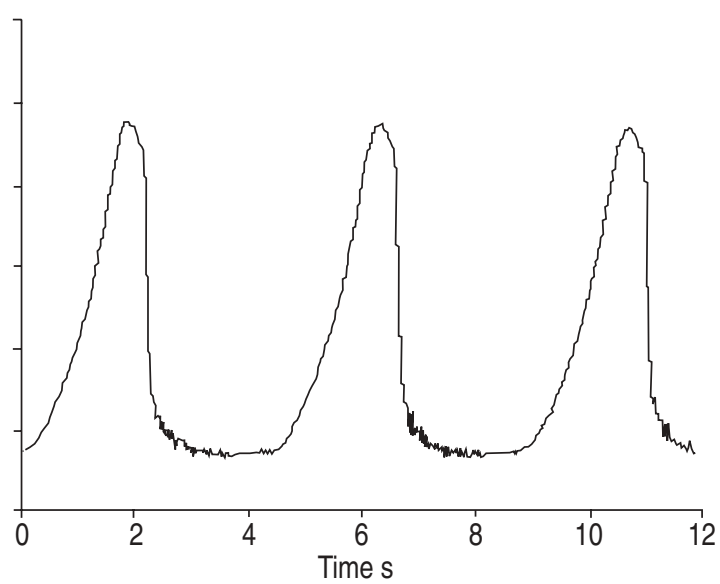

Fig. 1. - Representative tracings of air flow (add) and airway pressure $\left(P\right.$ aw; edh) in lungs ventilated with normal tidal volume $\left(6 \mathrm{~mL} \cdot \mathrm{kg}^{-1} ; \mathrm{a}, \mathrm{e}\right)$, large tidal volume $\left(12 \mathrm{~mL} \cdot \mathrm{kg}^{-1}\right)$ with high rate high flow (b, f), low rate high flow (c, g) and low rate low flow (d, h). Note that residual flow at end-expiration was zero, indicating air trapping was absent. 
sections were deparaffinised, rehydrated and stained for IL-8 and phospho-extracellular signal-regulated kinase (ERK)1/2. The primary antibodies were a goat-anti-human IL-8 antibody (Santa Cruz Biotechnology, Inc., Santa Cruz, CA, USA) and a monoclonal antibody against phospho-ERK1/2 respectively. The secondary antibodies were a biotin-conjugated donkey anti-goat immunoglobulin (Ig)G and goat anti-mouse $\mathrm{IgG}$ respectively (Jackson ImmunoReseach Laboratories, Inc., West Grove, PA, USA). Negative controls were done with irrelevant antibodies. The slides were examined with a Nikon microscope (Eclipse E600; Nikon USA, Melville, NY, USA) equipped with a digital camera and imaging software (QCapture, version 2.56; Quantitative Imaging Corporation, Burnaby, BC, Canada).

\section{Western blot analysis}

After the experiments, lung tissues were homogenised on ice in RIPA lysis buffer $(0.1 \%$ SDS, $0.5 \%$ deoxycholate, $1 \%$ Nonidet P-40 in PBS, pH 7.4) containing an antiprotease cocktail and $1 \mathrm{mM}$ vanadyl sulphate. Lung homogenates were centrifuged at $10,000 \times g$ for $10 \mathrm{~min}$, and the supernatants aliquoted. Samples were mixed with an equal volume of SDS-PAGE loading buffer $(0.125 \mathrm{M}$ Tris, $\mathrm{pH} 6.8,4 \%$ SDS, 20\% glycerol, 10\% $\beta$-mercaptoethanol, and $0.05 \%$ bromophenol blue), boiled and separated on 11\% SDSPAGE gels in Tris-glycine-SDS buffer. Electrophoresed proteins were blotted onto nitrocellulose, blocked with $3 \%$ milk in $50 \mathrm{mM}$ PBS ( $\mathrm{pH}$ 7.4) for $1 \mathrm{~h}$, washed with PBS- $0.05 \%$ Tween-20, and incubated overnight at $4{ }^{\circ} \mathrm{C}$ with primary antibodies in 5\% BSA in PBS-Tween. The primary antibodies were monoclonal antibodies against phospho-ERK1/2, phospho-p38, phospho-c-Jun N-terminal kinase (JNK), ERK1/2, p38 and JNK/stress-activated protein kinase (SAPK) (all from Cell Signaling Technology, Inc., Beverly, MA, USA). Blots were washed and incubated with horseradish peroxidaseconjugated secondary antibody (Santa Cruz Biotechnology) in 3\% milk in PBS-Tween for $1 \mathrm{~h}$ at room temperature. Protein bands were detected using chemiluminescence reagents and X-ray film (Amersham Life Science, Arlington Heights, IL, USA).

\section{Statistical analysis}

Data were expressed as mean \pm SE. Repeated measure analysis of variance (ANOVA) was used to analyse physiological data. One way ANOVA followed by Sheffe's test was used to analyse data. $\mathrm{p}$-values were reported where statistics was performed. A $\mathrm{p}<0.05$ was considered statistically significant.

\section{Results}

To find an optimal $V \mathrm{~T}$ to stretch the lung without overtly damaging the parenchyma, two other large tidal volumes $\left(16 \mathrm{~mL} \cdot \mathrm{kg}^{-1}\right.$ and $\left.24 \mathrm{~mL} \cdot \mathrm{kg}^{-1}\right)$ were tested in preliminary experiments using RR and I:E ratio similar to those in the $12 \mathrm{~mL} \cdot \mathrm{kg}^{-1}$ group. Both strategies produced severe alveolar oedema within $30 \mathrm{~min}$. Thus $12 \mathrm{~mL} \cdot \mathrm{kg}^{-1}$ was chosen for large $V \mathrm{~T}$ experiments.

\section{Physiological effects}

The control ventilation strategy $\left(6 \mathrm{~mL} \cdot \mathrm{kg}^{-1}\right)$ allowed stable $P$ pa and $P$ aw for $2 \mathrm{~h}$ with $<13 \mathrm{~g} \mathrm{WG}$ (table 2). During $2 \mathrm{~h}$ of HRHF ventilation, $P$ aw increased from $8.8 \pm 0.2 \mathrm{mmHg}$ to $24.3 \pm 0.9 \mathrm{mmHg}$. WG averaged $33 \mathrm{~g}$ or 2.5 fold that of the control group $(\mathrm{p}=0.038$, interaction $\mathrm{p}<0.0001)$. P pa ranged from $12-16 \mathrm{mmHg}$ during the $2 \mathrm{~h}$ and was similar to that of the control group. Microvascular pressure measured by the double occlusion technique was low (data not shown). Bovine albumin concentration in the BAL fluid was not elevated $\left(0.55 \pm 0.10 \mathrm{mg} \cdot \mathrm{mL}^{-1}\right.$ versus $0.33 \pm 0.08 \mathrm{mg} \cdot \mathrm{mL}^{-1}$ in the $6 \mathrm{~mL} \cdot \mathrm{kg}^{-1}$ group, $\left.\mathrm{p}=0.15\right)$.

Lungs ventilated with LRLF had lower WG $(\mathrm{p}=0.0045$, interaction $\mathrm{p}<0.0001$; table 2), and slightly lower $P$ aw compared to the HRHF group. $P$ pa and BAL albumin $\left(0.44 \pm 0.13 \mathrm{mg} \cdot \mathrm{mL}^{-1}\right)$ were unchanged. The LRHF group had WG, $P$ aw and $P$ pa similar to those of HRHF (table 2). BAL albumin remained low $\left(0.88 \pm 0.32 \mathrm{mg} \cdot \mathrm{mL}^{-1}, \mathrm{p}=0.15\right.$ versus HRHF; $\mathrm{p}=0.19$ versus $\left.6 \mathrm{~mL} \cdot \mathrm{kg}^{-1}\right)$. Compared to LRHF, LRLF lungs had lower $P$ aw (table 2). WG tended to be

Table 2. - Pulmonary artery pressure $(P$ pa), peak airway pressure $(P a w)$ and weight gain in lungs ventilated with normal tidal volume $\left(6 \mathrm{~mL} \cdot \mathrm{kg}^{-1}\right)$, large tidal volume $\left(12 \mathrm{~mL} \cdot \mathrm{kg}^{-1}\right)$ with high rate high flow (HRHF), low rate high flow (LRHF) and low rate low flow (LRLF)

Protocols

Time min

$\begin{array}{llllll}0 & 15 & 30 & 60 & 90 & 120\end{array}$

\begin{tabular}{|c|c|c|c|c|c|c|}
\hline \multicolumn{7}{|l|}{$P$ pa } \\
\hline $6 \mathrm{~mL} \cdot \mathrm{kg}^{-1}$ & $12.4 \pm 1.1$ & $13.4 \pm 1.4$ & $13.4 \pm 1.2$ & $13.9 \pm 1.4$ & $14.3 \pm 1.4$ & $15.2 \pm 1.6$ \\
\hline $12 \mathrm{~mL} \cdot \mathrm{kg}^{-1}+\mathrm{HRHF}$ & $13.8 \pm 1.1$ & $14.1 \pm 1.2$ & $14.4 \pm 1.4$ & $13.9 \pm 1.2$ & $14.5 \pm 0.8$ & $15.2 \pm 1.0$ \\
\hline $12 \mathrm{~mL} \cdot \mathrm{kg}^{-1}+\mathrm{LRHF}$ & $12.3 \pm 1.2$ & $13.6 \pm 1.4$ & $17.1 \pm 3.0$ & $12.6 \pm 1.0$ & $13.1 \pm 1.1$ & $13.6 \pm 1.2$ \\
\hline $12 \mathrm{~mL} \cdot \mathrm{kg}^{-1}+\mathrm{LRLF}$ & $12.3 \pm 0.9$ & $13.7 \pm 1.3$ & $15.4 \pm 1.8$ & $13.8 \pm 1.5$ & $12.5 \pm 1.2$ & $13.8 \pm 0.9$ \\
\hline \multicolumn{7}{|l|}{$P$ aw } \\
\hline $6 \mathrm{~mL} \cdot \mathrm{kg}^{-1}$ & $8.9 \pm 0.6$ & $8.9 \pm 0.6$ & $8.7 \pm 0.5$ & $8.8 \pm 0.5$ & $9.4 \pm 0.4$ & $9.6 \pm 0.3$ \\
\hline $12 \mathrm{~mL} \cdot \mathrm{kg}^{-1}+\mathrm{HRHF}$ & $8.8 \pm 0.2$ & $24.5 \pm 0.8$ & $23.8 \pm 0.6$ & $24.3 \pm 0.9$ & $24.0 \pm 0.9$ & $24.3 \pm 0.9 *$ \\
\hline $12 \mathrm{~mL} \cdot \mathrm{kg}^{-1}+\mathrm{LRHF}$ & $9.6 \pm 0.2$ & $25.6 \pm 0.7$ & $25.8 \pm 0.7$ & $25.6 \pm 0.6$ & $26.1 \pm 0.5$ & $26.3 \pm 0.7 *$ \\
\hline $12 \mathrm{~mL} \cdot \mathrm{kg}^{-1}+\mathrm{LRLF}$ & $9.7 \pm 0.3$ & $22.0 \pm 1.2$ & $22.1 \pm 1.3$ & $22.1 \pm 1.3$ & $21.4 \pm 1.3$ & $22.6 \pm 1.3^{*, \#}$ \\
\hline \multicolumn{7}{|l|}{ WG } \\
\hline $6 \mathrm{~mL} \cdot \mathrm{kg}^{-1}$ & $0.0 \pm 0.0$ & $1.6 \pm 0.2$ & $3.1 \pm 0.5$ & $5.9 \pm 0.7$ & $9.2 \pm 0.9$ & $12.8 \pm 1.5$ \\
\hline $12 \mathrm{~mL} \cdot \mathrm{kg}^{-1}+\mathrm{HRHF}$ & $0.0 \pm 0.0$ & $4.4 \pm 0.7$ & $8.3 \pm 1.1$ & $16.1 \pm 2.1$ & $24.1 \pm 3.5$ & $33.4 \pm 4.9 *$ \\
\hline $12 \mathrm{~mL} \cdot \mathrm{kg}^{-1}+\mathrm{LRHF}$ & $0.0 \pm 0.0$ & $2.7 \pm 0.3$ & $6.9 \pm 1.9$ & $13.7 \pm 4.9$ & $19.2 \pm 6.7$ & $25.9 \pm 9.0$ \\
\hline $12 \mathrm{~mL} \cdot \mathrm{kg}^{-1}+\mathrm{LRLF}$ & $0.0 \pm 0.0$ & $2.1 \pm 0.6$ & $4.2 \pm 0.8$ & $6.9 \pm 1.0$ & $10.1 \pm 1.3$ & $13.5 \pm 1.7^{\#}$ \\
\hline
\end{tabular}

Data are presented as mean \pm SE. $\mathrm{n}=6$ for $6 \mathrm{~mL} \cdot \mathrm{kg}^{-1}$; $=7$ for $12 \mathrm{~mL} \cdot \mathrm{kg}^{-1}+\mathrm{HRHF}$; $=6$ for $12 \mathrm{~mL} \cdot \mathrm{kg}^{-1}+\mathrm{LRHF}$; and $\mathrm{n}=7 \mathrm{for} 12 \mathrm{~mL} \cdot \mathrm{kg}^{-1}+\mathrm{LRLF}$. * $\mathrm{p}<$ 0.05 versus $6 \mathrm{~mL} \cdot \mathrm{kg}^{-1}$; ${ }^{\#}: \mathrm{p}<0.05$ versus $12 \mathrm{~mL} \cdot \mathrm{kg}^{-1}+\mathrm{HRHF}$. 


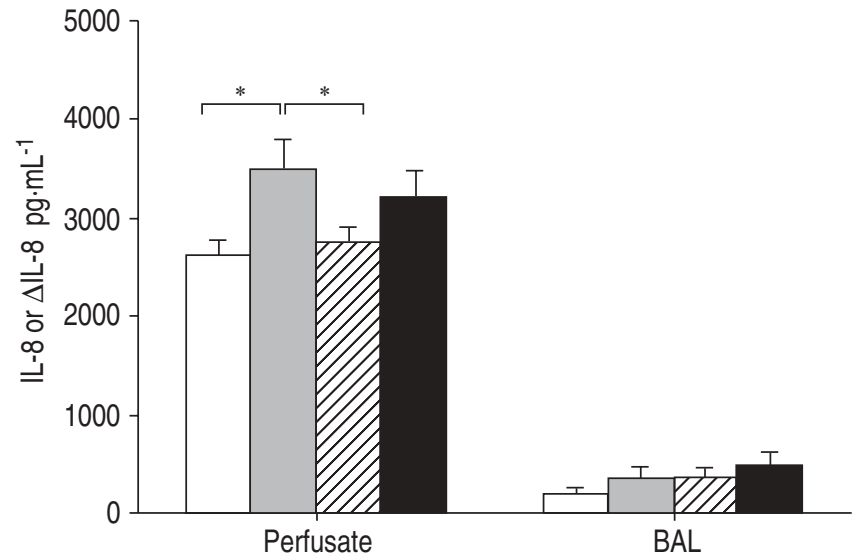

Fig. 2.-Changes $(\Delta)$ in interleukin (IL)-8 in the perfusate and bronchoalveolar lavage fluid produced by ventilation with normal tidal volume $\left(6 \mathrm{~mL} \cdot \mathrm{kg}^{-1} ; \square\right)$, large tidal volume $\left(12 \mathrm{~mL} \cdot \mathrm{kg}^{-1}\right)$ with high rate high flow (HRHF; ), low rate low flow (LRLF; $\mathbb{Z}$ ) and low rate high flow (LRHF; - for $2 \mathrm{~h}$. $\mathrm{n}=6$ for $6 \mathrm{~mL} \cdot \mathrm{kg}^{-1} ; \mathrm{n}=7$ for $12 \mathrm{~mL} \cdot \mathrm{kg}^{-1}+\mathrm{HRHF} ; \mathrm{n}=6$ for $12 \mathrm{~mL} \cdot \mathrm{kg}^{-1}+\mathrm{LRHF}$; and $\mathrm{n}=7$ for $12 \mathrm{~mL} \cdot \mathrm{kg}^{-1}+$ LRLF. *: $\mathrm{p}<0.05$.

lower, but the difference was not statistically significant (table 2). Ppa and BAL albumin were also not different.

\section{Effects on tumour necrosis factor- $\alpha$ and interleukin-8}

After $2 \mathrm{~h}$ of HRHF ventilation, vascular release of IL-8 increased by $\sim 40 \%$ compared to the control ( $\mathrm{p}=0.035$; fig. 2 ). BAL IL-8 was not different. Compared to HRHF, lungs ventilated with LRLF had lower IL-8 in the perfusate ( $\mathrm{p}=0.044$; fig. 2), similar to the control group. Lungs ventilated with LRHF had higher perfusate IL- 8 similar to the HRHF group (fig. 2).

TNF- $\alpha$ concentration in the perfusate and BAL was low, and showed minimal variations among the four groups. The only statistically significant change was that of BAL TNF- $\alpha$ between LRLF and LRHF (fig. 3).

HRHF resulted in strong IL-8 staining primarily in the smooth muscle of bronchioles with an internal diameter

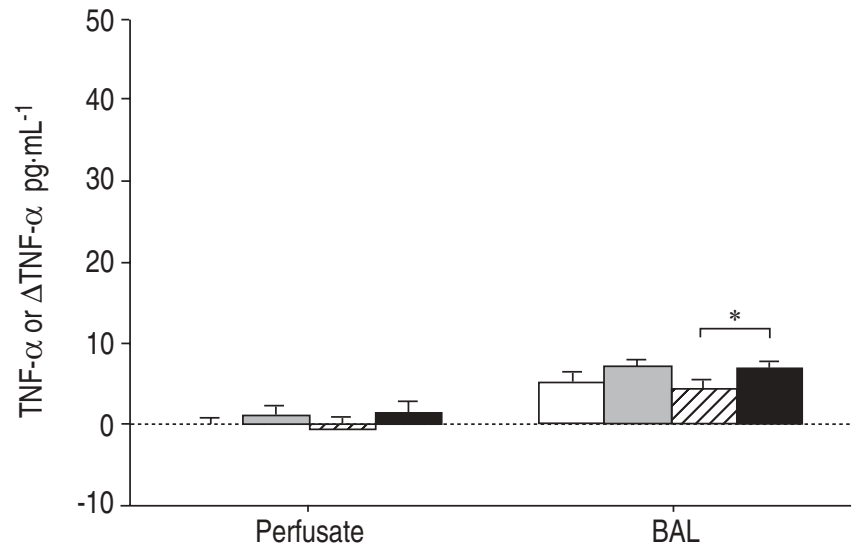

Fig. 3. - Changes $(\Delta)$ in tumour necrosis factor (TNF)- $\alpha$ in the perfusate and bronchoalveolar lavage fluid produced by ventilation with normal tidal volume $\left(6 \mathrm{~mL} \cdot \mathrm{kg}^{-1} ; \square\right)$, large tidal volume $\left(12 \mathrm{~mL} \cdot \mathrm{kg}^{-1}\right)$ with high rate high flow (HRHF; $)$, low rate low flow (LRLF; $\mathbb{Z}$ ) and low rate high flow (LRHF; ) for $2 \mathrm{~h}$. $\mathrm{n}=6$ for $6 \mathrm{~mL} \cdot \mathrm{kg}^{-1}$; $\mathrm{n}=7$ for $12 \mathrm{~mL} \cdot \mathrm{kg}^{-1}+\mathrm{HRHF}$; $=6$ for $12 \mathrm{~mL} \cdot \mathrm{kg}^{-1}+\mathrm{LRHF}$; and $\mathrm{n}=7$ for $12 \mathrm{~mL} \cdot \mathrm{kg}^{-1}+\mathrm{LRLF}$. *: $\mathrm{p}<0.05$.

$>1 \mathrm{~mm}$ and associated pulmonary arterioles (fig. 4). Significant IL-8 staining was absent in lungs ventilated with LRLF.

\section{Effects on mitogen-activated protein kinase activation}

After $2 \mathrm{~h}$ of HRHF ventilation, MAPK activation was detected as shown by increased phosphorylation of ERK1/2 (fig. 5), p38 (fig. 6) and SAPK/JNK (fig. 7). In lungs ventilated with LRHF, phosphorylation of ERK1/2, p38 and SAPK/JNK remained increased. In contrast, lungs ventilated with LRLF showed low MAPK activation similar to the control lungs.

In HRHF lungs, phospho-ERK1/2 staining increased primarily in bronchial epithelial cells and pulmonary artery smooth muscles and adventitia (fig. 8). Similar to IL-8, phospho-ERK1/2 staining increased primarily in bronchioles $>1 \mathrm{~mm}$ in internal diameter and associated pulmonary arterioles. The staining was absent in the LRLF group and
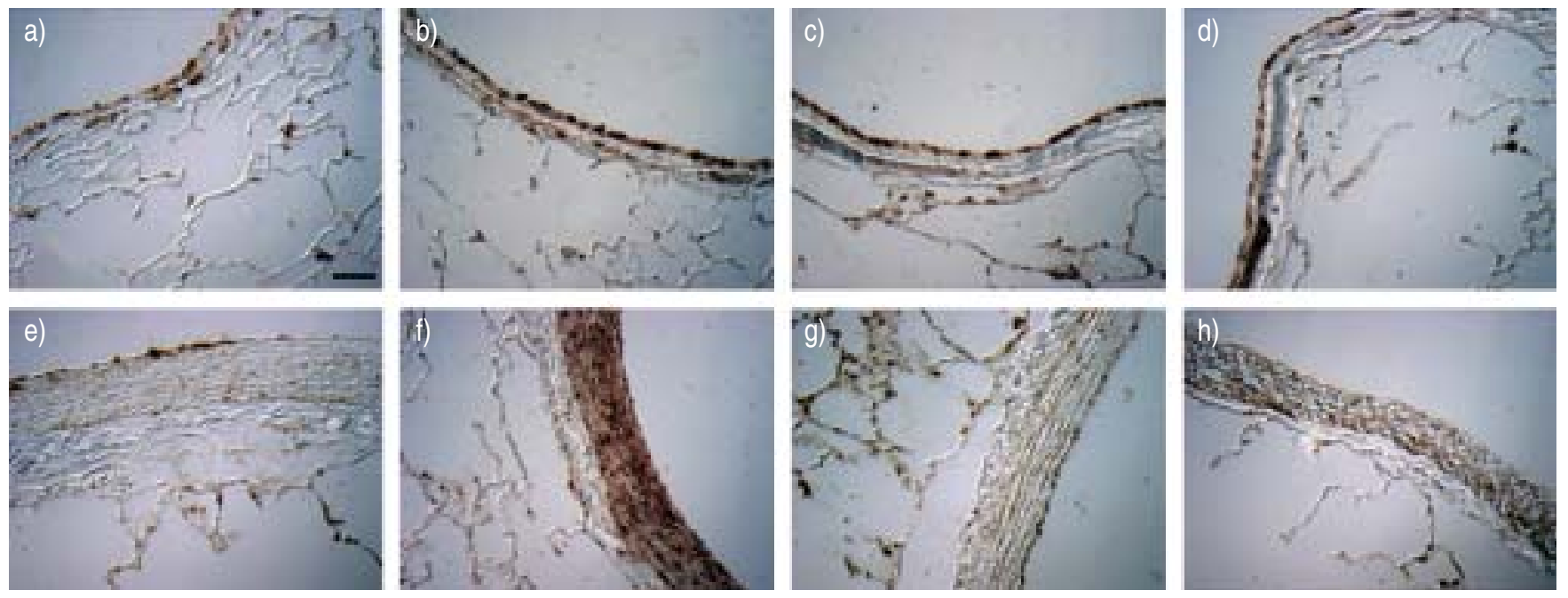

Fig. 4. - Immunocytochemistry for interleukin (IL)-8 in the lung (a-d: bronchiole; e-h: pulmonary artery) ventilated with normal tidal volume $\left(6 \mathrm{~mL} \cdot \mathrm{kg}^{-1} ; \mathrm{a}, \mathrm{e}\right)$, large tidal volume $\left(12 \mathrm{~mL} \cdot \mathrm{kg}^{-1}\right)$ with high rate high flow (b, f), low rate low flow (c, g) and low rate high flow (d, h) for $2 \mathrm{~h}$. Scale bar $=10 \mu \mathrm{m}$. 


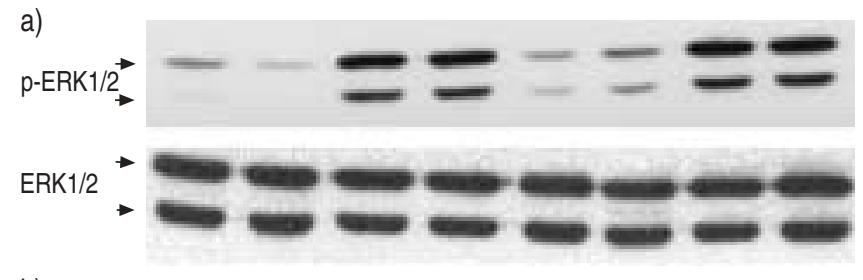

b)

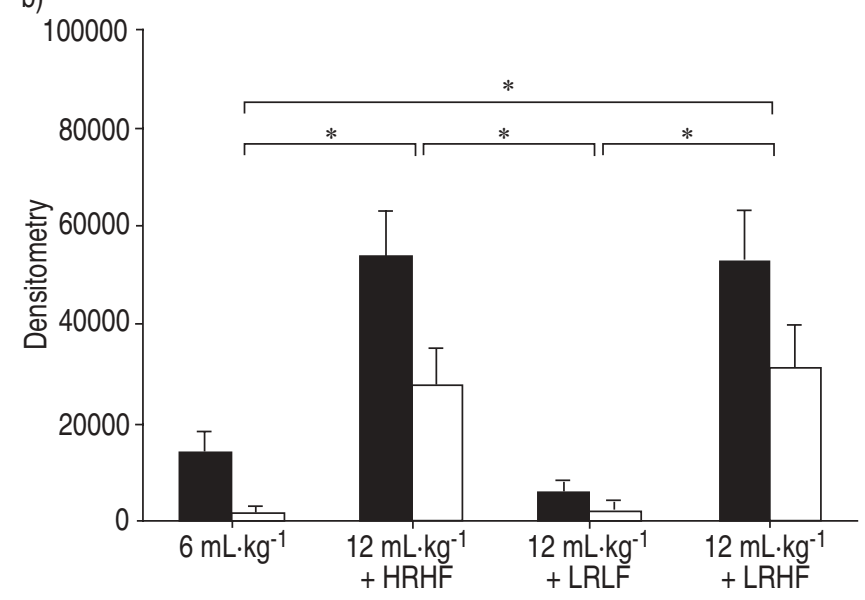

Fig. 5.-Phosphorylation of extracellular signal-regulated kinase (ERK) $1 / 2$ after lungs were ventilated with normal tidal volume $\left(6 \mathrm{~mL} \cdot \mathrm{kg}^{-1}\right)$, large tidal volume $\left(12 \mathrm{~mL} \cdot \mathrm{kg}^{-1}\right)$ with high rate high flow (HRHF), low rate high flow (LRHF) and low rate low flow (LRLF) for $2 \mathrm{~h}$. a) Representative Western blot for phosphorylated ERK1/2 (p-ERK1/2) and total ERK1/2. Each lane represents an independent experiment. b) Densitometry results for p-ERK1/2 (ם: p-ERK/1; $\square$ : p-ERK/2). $n=4$ separate experiments. *: $\mathrm{p}<0.05$.

intermediate in the LRHF group. There was no increased staining in alveoli or pulmonary venules (data not shown).

\section{Discussion}

The major new findings of this study were that HRHF ventilation increased lung IL-8 release and activated lung MAPK, both of which were absent during LRLF ventilation. Although changes in IL-8 and MIP-2 have been noted in other studies of isolated lungs [10, 12, 30-33] and of lungs ventilated with moderately large $V \mathrm{~T}$ (up to $20 \mathrm{~mL} \cdot \mathrm{kg}^{-1}$ ) in vivo $[9,34]$, inspiratory flow rate was not controlled. IL-8 is important because it is a potent neutrophil chemoattractant that is increased in patients with sepsis and persistent acute respiratory distress syndrome [35-37]. Furthermore, increased levels of anti-IL-8:IL-8 complexes are associated with increased mortality [38]. IL-8 is also angiogenic and induces proliferation and chemotaxis of endothelial cells and smooth muscle cells [39]. Several resident cells in the lung can produce IL-8 with mechanical stress, including epithelial cells [5, 6, 18] and alveolar macrophages [5]. The immunochemical staining in the current study indicates that smooth muscle cells of larger pulmonary arterioles and bronchioles were also sources of IL-8 release.

A growing body of evidence indicates that MAPK activation is an early event in signalling from mechanosensors to nucleus to stimulate gene transcription [40]. Rapid phosphorylation of ERK, p38 and SAPK/JNK has been observed in cultured lung cells submitted to cyclic stretch [16, 18, 41]. Phosphorylation of ERK1/2 and SAPK/JNK was found in adult rats ventilated with an injurious high pressure (peak inspiratory pressure/ $\mathrm{PEEP}=45 / 10 \mathrm{cmH}_{2} \mathrm{O}$ ) [15] and activation

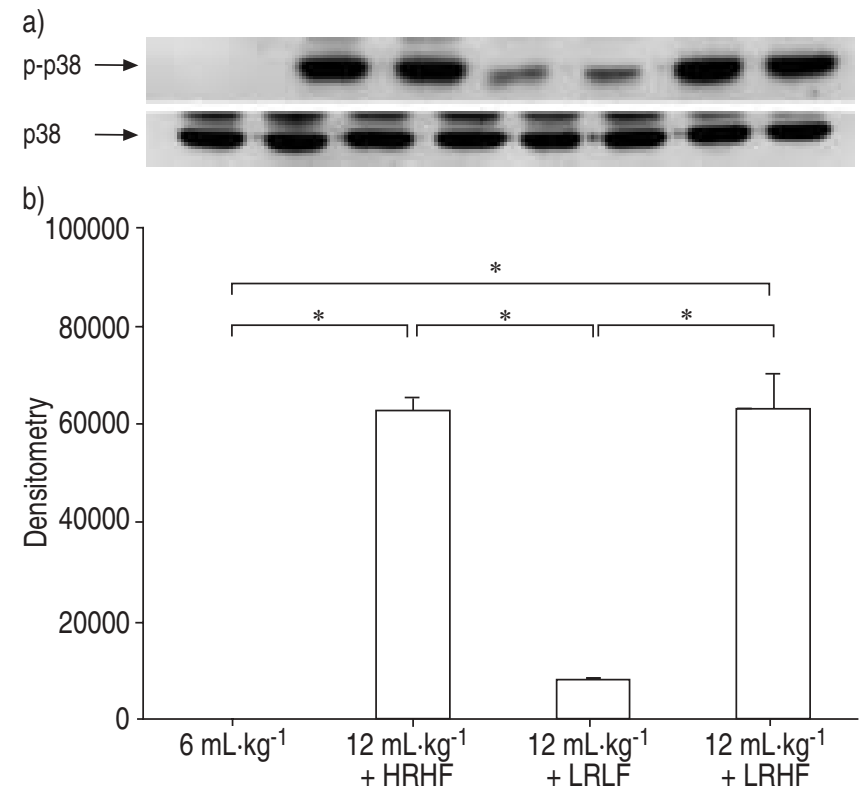

Fig. 6. - Phosphorylation of p38 after lungs were ventilated with normal tidal volume $\left(6 \mathrm{~mL} \cdot \mathrm{kg}^{-1}\right)$, large tidal volume $\left(12 \mathrm{~mL} \cdot \mathrm{kg}^{-1}\right)$ with high rate high flow (HRHF), low rate high flow (LRHF) and low rate low flow (LRLF) for $2 \mathrm{~h}$. a) Representative Western blot for phosphorylated p38 (p-p38) and total p38. Each lane represents an independent experiment. b) Densitometry results for $\mathrm{p}-\mathrm{p} 38 . \mathrm{n}=4$ separate experiments. ${ }^{*}: \mathrm{p}<0.05$.


Fig. 7. - Phosphorylation of stress-activated protein kinase (SAPK)/cJun N-terminal kinase (JNK) after lungs were ventilated with normal tidal volume $\left(6 \mathrm{~mL} \cdot \mathrm{kg}^{-1}\right)$, large tidal volume $\left(12 \mathrm{~mL} \cdot \mathrm{kg}^{-1}\right)$ with high rate high flow (HRHF), low rate high flow (LRHF) and low rate low flow (LRLF) for $2 \mathrm{~h}$. a) Representative Western blot for phosphorylated JNK (p-JNK) and total JNK. Each lane represents an independent experiment. b) Densitometry results for p-JNK ( $\mathbf{0}: \mathrm{p}-$ JNK2/3; $\square$ : $\mathrm{p}-J N K 1) . \mathrm{n}=4$ separate experiments. *: $\mathrm{p}<0.05$.

of ERK1/2 and SAPK/JNK was found in alveolar epithelial cells. In the current study, lungs ventilated with lower peak inspiratory pressure/PEEP $\left(35 / 3 \mathrm{cmH}_{2} \mathrm{O}\right)$ also activated ERK1/2, 

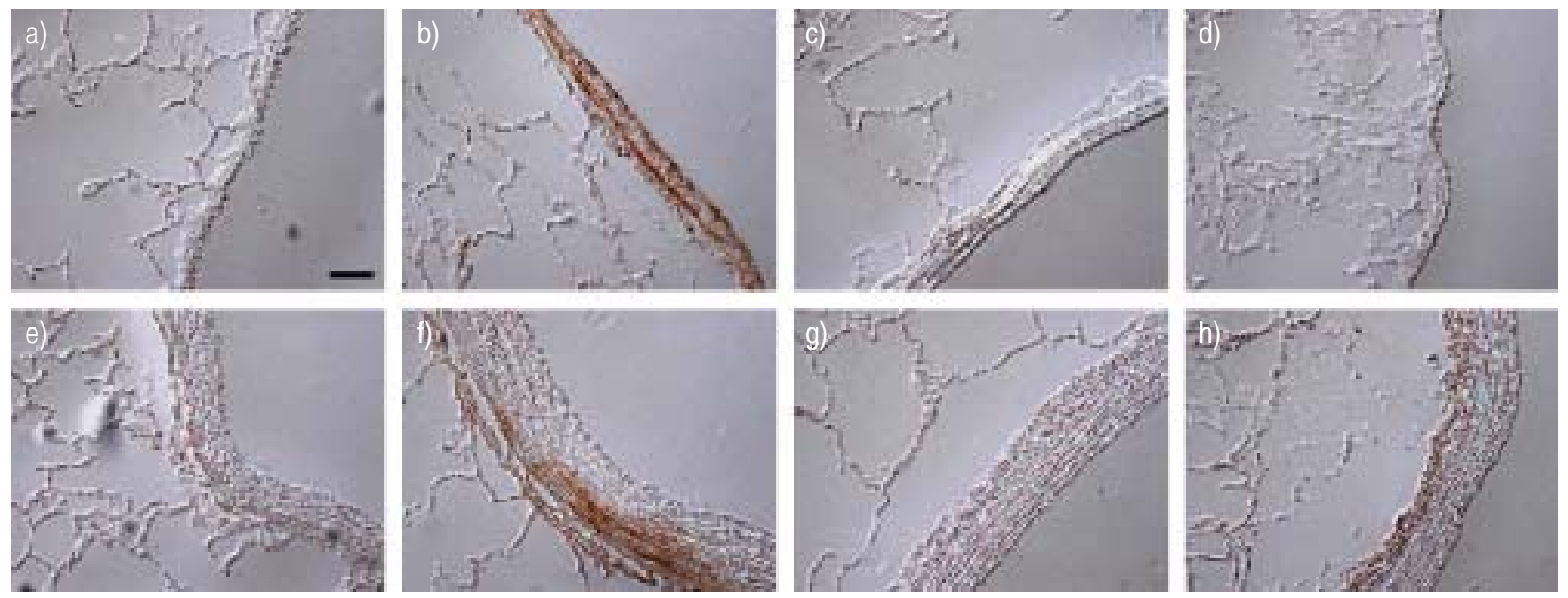

Fig. 8. - Immunocytochemistry for phosphorylated extracellular signal-regulated kinase (ERK)1/2 in the lung (a-d: bronchiole; e-h: pulmonary artery) ventilated with normal tidal volumes $\left(6 \mathrm{~mL} \cdot \mathrm{kg}^{-1} ; \mathrm{a}, \mathrm{e}\right)$, large tidal volume $\left(12 \mathrm{~mL} \cdot \mathrm{kg}^{-1}\right)$ with high rate high flow (b, f), low rate low flow $(\mathrm{c}, \mathrm{g})$ and low rate high flow $(\mathrm{d}, \mathrm{h})$ for $2 \mathrm{~h}$. Scale bar=10 $\mu \mathrm{m}$.

p38 and SAPK/JNK. Activation of ERK1/2 was most prominent in larger pulmonary arterioles and bronchioles. The differences in cellular distribution may be related to the degree of lung stretch injury relative to the magnitude of flow shear stress (see below).

Perhaps the most important finding of the present study was that IL-8 release and MAPK activation during HRHF could be prevented by reducing inspiratory flow (LRLF). During inflation, lung parenchyma and airways are subject to both tensile stress and shear stress [42]. Tensile stress acts perpendicularly to the surface and its magnitude is determined by transpulmonary pressure. Shear stress acts in a primarily parallel direction to the surface and, the magnitude of shear stress with laminar flow is determined by the viscosity, average flow velocity and the diameter of the airway:

$$
\text { Laminar shear stress }\left(\tau_{\mathrm{w}}\right)=8 \times \mu \times(\mathrm{V} / \mathrm{D})
$$

Where $\mu$ is the viscosity of air; $\mathrm{V}$ is average flow velocity (volumetric flow rate divided by tube area, $\pi \mathrm{D}^{2} / 4$ ); and $\mathrm{D}$ is the tube diameter. The HRHF protocol of the current study used a $V \mathrm{~T}$ of $12 \mathrm{~mL} \cdot \mathrm{kg}^{-1}$ to ventilate the lung at 30 breaths per min and an I:E ratio of $1: 1$ resulting in an average inspiratory flow of $12 \mathrm{~mL} \cdot \mathrm{kg} \cdot \mathrm{s}^{-1}$. Assuming the viscosity of air is $1.73 \times 10^{-5} \mathrm{~N}-\mathrm{s} \cdot \mathrm{m}^{-2}$, the laminar shear stress at the rabbit trachea (internal diameter $=6 \mathrm{~mm}$ ) during $\mathrm{HRHF}$ ventilation would be $\sim 0.03 \mathrm{~N} \cdot \mathrm{m}^{-2}$. At large airways where the flow is primarily turbulent, Reynold's stress dominates and can be several hundredfold higher than the laminar shear stress (3-10 $\mathrm{N} \cdot \mathrm{m}^{-2}$ ). Even in lower airways with an internal diameter of $0.6 \mathrm{~mm}$ (8-10th generation) where the volumetric flow rate has fallen significantly, wall shear stress may still be significant, especially at airway bifurcations and curvature [43]. This concept is supported by the increased IL-8 and ERK1/2 immunostaining in bronchioles $>1 \mathrm{~mm}$ in internal diameter. The current findings did not exclude the contribution of lung oedema or the higher velocity of perpendicular stress applied to alveolar surface in the HRHF group to IL-8 release and the degree of MAPK activation. However, this effect would be much less than in previous studies where very large tidal volumes were used and tissue destruction was pronounced [10, 12, 30-33].

Fluid-induced shear stress in the range of $0.5-5 \mathrm{~N} \cdot \mathrm{m}^{-2}$ activates MAPK, enhances inflammatory cytokine release, induces gene expression, and regulates cytoskeletal alignment and cell proliferation in vascular endothelial and smooth muscle cells [20, 44-51]. Little is known, however, about the biochemical effects of shear stress produced by high airflow on pulmonary cells or in the lung. High inspiratory flow should produce the greatest impact on the epithelium of larger airways and surrounding structures as high tangential forces on the epithelium create horizontal deflection of plasma membranes relative to internal structures, e.g. cytoskeleton elements [52]. Such distortion may activate deformation-sensitive membraneand cytoskeleton-mediated mechanotransduction [53]. Using finite element analysis, LAI-FOOK and KALLOK [54] studied interactions between the artery and bronchus, and found that distorting forces applied to bronchus or artery produce nonuniform stress around both structures. The stress concentration is several times the mean periarterial and peribronchial radial stress at the interstitial space adjoining the artery and bronchus. These analyses suggest that stress on the bronchial wall may be transmitted to adjacent artery via the interstitium and that the interstitum within the bronchoarterial sheath may be the focal point of tears during lung hyperinflation. The profuse IL-8 and MAPK staining in and around the pulmonary artery (smooth muscle and adventitia) at high flow in the current study provides evidence for this hypothesis. The mechanosensors responsible are not known; such structures on bronchial epithelial cells are not well defined, but candidates include integrin receptors [55], amiloridesensitive sodium channels [56-58], and perhaps cilia [52].

The prominent effects of HRHF on IL- 8 and MAPK were in contrast to the relatively minor effects on TNF- $\alpha$. It is possible that the mechanical stress during HRHF ventilation might not have been sufficient to trigger $\mathrm{TNF}-\alpha$ release. Several studies using larger $V \mathrm{~T}$ have demonstrated increased TNF- $\alpha$ in BAL $[8,31,33]$ while others did not $[30,59,60]$. It is possible that $\mathrm{TNF}-\alpha$ release is accentuated by simultaneous insults, e.g., endotoxin [17,30] or ischaemia [8]. The lack of an intact bronchial circulation in isolated lungs may also influence the cellular responses.

In conclusion, the current authors report that inspiratory flow is an important mechanical determinant of vascular interleukin-8 release and mitogen-activated protein kinase activation during mild lung stretch, and the main effects occur on cells within larger bronchopulmonary structures. In injured lungs subject to mechanical ventilation, substantial 
increases in tensile stresses are caused by increased surface tension and repeated opening and closing of unstable alveolar units [42]. Application of positive end-expiratory pressure alleviates some of these stresses by preventing derecruitment of unstable alveoli [34]. The study suggests that high inspiratory flow rates may also stimulate larger airways and pulmonary arterioles to release inflammatory mediators, and that reducing inspiratory flow might provide additional lung protection.

\footnotetext{
Acknowledgements. The authors thank L. Tatro of Duke University Medical Center and J. Soukup, J. Carter of US Environmental Protection Agency for technical support. The study was supported by a grant from NHLBI (P01HL073997)
}

\section{References}

1. Egan EA. Lung inflation, lung solute permeability, and alveolar edema. J Appl Physiol 1982; 53: 121-125.

2. West JB, Tsukimoto K, Mathieu-Costello O, Prediletto R. Stress failure in pulmonary capillaries. J Appl Physiol 1991; 70: 1731-1742.

3. Belperio JA, Keane MP, Burdick MD, et al. Critical role for CXCR2 and CXCR2 ligands during the pathogenesis of ventilator-induced lung injury. J Clin Invest 2002; 110: 17031716.

4. Dos Santos CC, Slutsky AS. Invited review: mechanisms of ventilator-induced lung injury: a perspective. J Appl Physiol 2000; 89: 1645-1655.

5. Pugin J, Dunn I, Jolliet P, et al. Activation of human macrophages by mechanical ventilation in vitro. Am J Physiol 1998; 275: L1040-L1050.

6. Vlahakis NE, Schroeder MA, Limper AH, Hubmayr RD. Stretch induces cytokine release by alveolar epithelial cells in vitro. Am J Physiol 1999; 277: L167-L173.

7. The Acute Respiratory Distress Syndrome Network. Ventilation with lower tidal volumes as compared with traditional tidal volumes for acute lung injury and the acute respiratory distress syndrome. N Engl J Med 2000; 342: 1301-1308.

8. Tremblay L, Valenza F, Ribeiro SP, Li J, Slutsky AS. Injurious ventilatory strategies increase cytokines and c-fos m-RNA expression in an isolated rat lung model. $J$ Clin Invest 1997; 99: 944-952.

9. Quinn DA, Moufarrej RK, Volokhov A, Hales CA. Interactions of lung stretch, hyperoxia, and MIP-2 production in ventilator-induced lung injury. J Appl Physiol 2002; 93: 517-525.

10. Held HD, Boettcher S, Hamann L, Uhlig S. Ventilationinduced chemokine and cytokine release is associated with activation of nuclear factor-kappaB and is blocked by steroids. Am J Respir Crit Care Med 2001; 163: 711-716.

11. Stamme C, Brasch F, von Bethmann A, Uhlig S. Effect of surfactant on ventilation-induced mediator release in isolated perfused mouse lungs. Pulm Pharmacol Ther 2002; 15: 455461.

12. von Bethmann AN, Brasch F, Nusing R, et al. Hyperventilation induces release of cytokines from perfused mouse lung. Am J Respir Crit Care Med 1998; 157: 263-272.

13. von Bethmann A, Brasch F, Muller KM, Wendel A, Uhlig S. Prolonged hyperventilation is required for release of tumor necrosis factor- $\alpha$ but not IL-6. Appl Cardiopulm Pathol 1996; 6: $171-177$.

14. Imai $\mathrm{Y}$, Kawano $\mathrm{T}$, Iwamoto S, Nakagawa S, Takata M, Miyasaka K. Intratracheal anti-tumor necrosis factor-alpha antibody attenuates ventilator-induced lung injury in rabbits. J Appl Physiol 1999; 87: 510-515.

15. Uhlig U, Haitsma JJ, Goldmann T, Poelma DL, Lachmann
B, Uhlig S. Ventilation-induced activation of the mitogenactivated protein kinase pathway. Eur Respir $J$ 2002; 20 : 946-956.

16. Chess PR, Toia L, Finkelstein JN. Mechanical straininduced proliferation and signaling in pulmonary epithelial H441 cells. Am J Physiol Lung Cell Mol Physiol 2000; 279: L43-L51.

17. Mourgeon E, Isowa N, Keshavjee S, Zhang X, Slutsky AS, Liu M. Mechanical stretch stimulates macrophage inflammatory protein-2 secretion from fetal rat lung cells. $\mathrm{Am}$ J Physiol Lung Cell Mol Physiol 2000; 279: L699-L706.

18. Oudin S, Pugin J. Role of MAP kinase activation in interleukin- 8 production by human BEAS- 2B bronchial epithelial cells submitted to cyclic stretch. Am J Respir Cell Mol Biol 2002; 27: 107-114.

19. Vlahakis NE, Schroeder MA, Pagano RE, Hubmayr RD. Deformation-induced lipid trafficking in alveolar epithelial cells. Am J Physiol Lung Cell Mol Physiol 2001; 280: L938L946.

20. Chien S, Li S, Shyy YJ. Effects of mechanical forces on signal transduction and gene expression in endothelial cells. Hypertension 1998; 31: 162-169.

21. Du W, Mills I, Sumpio BE. Cyclic strain causes heterogeneous induction of transcription factors, AP-1, CRE binding protein and NF-kB, in endothelial cells: species and vascular bed diversity. J Biomech 1995; 28: 1485-1491.

22. Lai-Fook SJ. Stress distribution. In: Crystal RG, West JB, eds. The Lung: Scientific Foundations. New York, Raven Press Ltd, 1991; pp. 829-838.

23. Huang YC, Fisher PW, Nozik-Grayck E, Piantadosi CA. Hypoxia compared to normoxia alters the effects of nitric oxide in ischemia-reperfusion lung injury. Am $J$ Physiol (Lung Cell Mol Physiol) 1997; 273: L504-L512.

24. Huang YT, Ghio AJ, Nozik-Grayck E, Piantadosi CA. Vascular release of nonheme iron in perfused rabbit lungs. Am J Physiol Lung Cell Mol Physiol 2001; 280: L474-L481.

25. Huang $\mathrm{YC}, \mathrm{Wu} \mathrm{W}$, Ghio AJ, et al. Activation of EGF receptors mediates pulmonary vasoconstriction induced by residual oil fly ash. Exp Lung Res 2002; 28: 19-38.

26. Samet JM, Silbajoris R, Huang T, Jaspers I. Transcription factor activation following exposure of an intact lung preparation to metallic particulate matter. Environ Health Perspect 2002; 110: 985-990.

27. Fisher AB, Dodia C, Ayene I, Al-Medhi A. Ischemiareperfusion injury to the lung. Ann NY Acad Sci 1994; 723: 197-207.

28. Kolobow $\mathrm{T}$, Moretti MP, Fumagalli $\mathrm{R}$, et al. Severe impairment in lung function induced by high peak airway pressure during mechanical ventilation. An experimental study. Am Rev Respir Dis 1987; 135: 312-315.

29. Huang YC, Piantadosi CA. Alveolar barrier function assessed by hydrophobic and hydrophilic fluorescent solutes in rabbit lung. Respir Physiol Neurobiol 2002; 133: 153-166.

30. Ricard JD, Dreyfuss D, Saumon G. Production of inflammatory cytokines in ventilator-induced lung injury: a reappraisal. Am J Respir Crit Care Med 2001; 163: 11761180 .

31. Tremblay LN, Miatto D, Hamid Q, Govindarajan A, Slutsky AS. Injurious ventilation induces widespread pulmonary epithelial expression of tumor necrosis factor-alpha and interleukin-6 messenger RNA. Crit Care Med 2002; 30: $1693-1700$.

32. Veldhuizen RA, Slutsky AS, Joseph M, McCaig L. Effects of mechanical ventilation of isolated mouse lungs on surfactant and inflammatory cytokines. Eur Respir J 2001; 17: 488-494.

33. Welk B, Malloy JL, Joseph M, Yao LJ, Veldhuizen AW. Surfactant treatment for ventilation-induced lung injury in rats: effects on lung compliance and cytokines. Exp Lung Res 2001; 27: 505-520.

34. Chiumello D, Pristine G, Slutsky AS. Mechanical ventilation affects local and systemic cytokines in an animal model of 
acute respiratory distress syndrome. Am J Respir Crit Care Med 1999; 160: 109-116.

35. Goodman RB, Strieter RM, Martin DP, et al. Inflammatory cytokines in patients with persistence of the acute respiratory distress syndrome. Am J Respir Crit Care Med 1996; 154: 602-611.

36. Miller EJ, Cohen AB, Matthay MA. Increased interleukin-8 concentrations in the pulmonary edema fluid of patients with acute respiratory distress syndrome from sepsis. Crit Care Med 1996; 24: 1448-1454.

37. Schutte H, Lohmeyer J, Rosseau S, et al. Bronchoalveolar and systemic cytokine profiles in patients with ARDS, severe pneumonia and cardiogenic pulmonary oedema. Eur Respir $J$ 1996; 9: 1858-1867.

38. Kurdowska A, Noble JM, Steinberg KP, Ruzinski JT, Hudson LD, Martin TR. Anti-interleukin 8 autoantibody: interleukin 8 complexes in the acute respiratory distress syndrome. Relationship between the complexes and clinical disease activity. Am J Respir Crit Care Med 2001; 163: 463468.

39. Yue TL, Wang X, Sung CP, et al. Interleukin-8. A mitogen and chemoattractant for vascular smooth muscle cells. Circ Res 1994; 75: 1-7.

40. Pugin J. Molecular mechanisms of lung cell activation induced by cyclic stretch. Crit Care Med 2003; 31: Suppl. 4, S200-S206.

41. Correa-Meyer E, Pesce L, Guerrero C, Sznajder JI. Cyclic stretch activates ERK1/2 via $G$ proteins and EGFR in alveolar epithelial cells. Am J Physiol Lung Cell Mol Physiol 2002; 282: L883-L891.

42. Rodarte JR, Fung YC. Distribution of stresses within the lung. In: Macklem PT, Mead J, eds. Handbook of Physiology, Section 3. The Respiratory System. Bethesda, American Physiological Society, 1986; pp. 233-245.

43. Pedley TJ, Kamm RD. Dynamics of gas flow and pressureflow relationships. In: Crystal RG, West JB, eds. The Lung: Scientific Foundations. New York, Raven Press Ltd, 1991; pp. 995-1009.

44. Azuma N, Duzgun SA, Ikeda M, et al. Endothelial cell response to different mechanical forces. J Vasc Surg 2000; 32: 789-794.

45. Azuma N, Akasaka N, Kito $\mathrm{H}$, et al. Role of p38 MAP kinase in endothelial cell alignment induced by fluid shear stress. Am J Physiol Heart Circ Physiol 2001; 280: H189H197.

46. Bao X, Lu C, Frangos JA. Mechanism of temporal gradients in shear-induced ERK1/2 activation and proliferation in endothelial cells. Am J Physiol Heart Circ Physiol 2001; 281: $\mathrm{H} 22-\mathrm{H} 29$.

47. Butler PJ, Tsou TC, Li JY, Usami S, Chien S. Rate sensitivity of shear-induced changes in the lateral diffusion of endothelial cell membrane lipids: a role for membrane perturbation in shear-induced MAPK activation. FASEB $J$ 2002; 16: 216-218.

48. Go YM, Boo YC, Park $\mathrm{H}$, et al. Protein kinase B/Akt activates c-Jun $\mathrm{NH}(2)$-terminal kinase by increasing $\mathrm{NO}$ production in response to shear stress. J Appl Physiol 2001; 91: $1574-1581$.

49. Labrador V, Chen KD, Li YS, Muller S, Stoltz JF, Chien S. Interactions of mechanotransduction pathways. Biorheology 2003; 40: 47-52.

50. Schwachtgen JL, Houston P, Campbell C, Sukhatme V, Braddock M. Fluid shear stress activation of egr-1 transcription in cultured human endothelial and epithelial cells is mediated via the extracellular signal-related kinase $1 / 2$ mitogen-activated protein kinase pathway. $J$ Clin Invest 1998; 101: 2540-2549.

51. Sterpetti AV, Cucina A, Morena AR, et al. Shear stress increases the release of interleukin- 1 and interleukin- 6 by aortic endothelial cells. Surgery 1993; 114: 911-914.

52. Gillespie PG, Walker RG. Molecular basis of mechanosensory transduction. Nature 2001; 413: 194-202.

53. Shafrir Y, Forgacs G. Mechanotransduction through the cytoskeleton. Am J Physiol Cell Physiol 2002; 282: C479-486.

54. Lai-Fook SJ, Kallok MJ. Bronchial-arterial interdependence in isolated dog lung. J Appl Physiol 1982; 52: 1000-1007.

55. Schmidt C, Pommerenke H, Durr F, Nebe B, Rychly J. Mechanical stressing of integrin receptors induces enhanced tyrosine phosphorylation of cytoskeletally anchored proteins. J Biol Chem 1998; 273: 5081-5085.

56. Hong K, Driscoll M. A transmembrane domain of the putative channel subunit MEC-4 influences mechanotransduction and neurodegeneration in C. elegans. Nature 1994; 367: 470-473

57. Huang M, Chalfie M. Gene interactions affecting mechanosensory transduction in Caenorhabditis elegans. Nature 1994; 367: 467-470.

58. Waters CM, Ridge KM, Sunio G, Venetsanou K, Sznajder JI. Mechanical stretching of alveolar epithelial cells increases $\mathrm{Na}(+)-\mathrm{K}(+)-$ ATPase activity. J Appl Physiol 1999; 87: 715721 .

59. Haitsma JJ, Uhlig S, Goggel R, Verbrugge SJ, Lachmann U, Lachmann B. Ventilator-induced lung injury leads to loss of alveolar and systemic compartmentalization of tumor necrosis factor-alpha. Intensive Care Med 2000; 26: 15151522.

60. Verbrugge SJ, Uhlig S, Neggers SJ, et al. Different ventilation strategies affect lung function but do not increase tumor necrosis factor-alpha and prostacyclin production in lavaged rat lungs in vivo. Anesthesiology 1999; 91: 1834 1843. 